\title{
Building the Global Value Chain Dominated by Chinese Enterprises under the "One Belt One Road” Proposal
}

\author{
Haiyan Zhou \\ International Business Research Center \\ Zhejiang University of Finance \& Economics \\ Hang Zhou, China
}

\author{
Zhimin Ren, Yueyue Zhang, Xiaoping Wang, Hui Li, \\ Feng $\mathrm{Hu} *$ \\ Global Value Chain Research Center \\ Zhejiang Gongshang University \\ Hang Zhou, China \\ *Hufeng616@188.com
}

\begin{abstract}
After the "one belt one road" was proposed, the "one belt one road" cooperation blueprint has been gradually developed from nil to some and from point to surface, which provides a development scheme with Chinese wisdom, joint negotiation, joint building, sharing, cooperation and win-win to the world, and also input new driving force into the recovery and long term development of the global economy. The "one belt one road" goes through the Europe-Asia Land, east to the AsiaPacific economic circle and west to the Europe an economic circle. Focusing on the large Europe-Asia stage, "one belt one road" determines the pattern of the world development. China's "one belt one road" proposal provides a brand new thinking for the partners, say, rebuilding the new global economy order by cooperative construction and improving the global value chain. China is now transferring from the economy led by investment and export to the one led by domestic demand, which affects the global trade. In future, China will build its own global value chain network by the strategies such as the "one belt one road" and etc.
\end{abstract}

Keywords-“one belt one road” proposal; global value chain; going out strategy; sharing

\section{INTRODUCTION}

2100 years ago, Mr. Zhang Qian went to the western area and opened up the land "Silk Road" from east to west and linking Europe and Asia. At the same time, since Qin-Han era which is over 2000 years ago, the sea "Silk Road" linking China and the European-Asian countries has also been gradually emerged. Both the land "Silk Road" and the sea "Silk Road" are the path for the transportation, trade and cultural contact between China and the European-Asian countries, and promote the cultural communication of the east and west, as well as the friendly association of the people. At the new historic stage, building the economic corridor along the land and sea "Silk Road" will provide the opportunity for both China and the countries and areas along the line, and expand wider development space. Under the current background of the slow recovery of the global economy, strengthening the regional cooperation is the important driving

This thesis was supported by National Natural Science Fund Projects (No. 71773115), Humanity and Social Science Foundation of Ministry of

Education in China(No.17YJA630028/17YJC630060), Natural Science

Foundation of Zhejiang Province (No.LQ18G030009) and Philosophy and

Society Science Foundation of Zhejiang Province (No.18NDJC147YB). force for the world economy development and has become the trend. In September and October of 2013, when Chinese President $\mathrm{Xi}$ Jinping visited middle Asian and South-east Asian countries, he proposed the strategic concept of "Silk Road Economic Belt" and " $21^{\text {st }}$ century sea Silk Road", which attracted high attention of the international society and get active response from relevant countries. Co-building "one belt one road" is the strategic concept proposed by Chinese government according to the changes of the international and regional situation as well as the new task for China's development to maintain the global free trade system and the opening economic system, and promote the cooperation and development of the countries along the line, which indicates the deep time background. At present, the governments of various levels in China actively participate in the "one belt one road" construction, but many governments still have no specific thoughts. Some even interpret it as the new measures of policy preferential and tax preferential as well as the new chance for the investment, rather than the new opportunity for the opening and reform. The government and enterprises should not construct "one belt one road" separately; instead they should combine the "going out" strategy and the optimized upgrade of the industry structure, take the opportunity of "one belt one road" to improve foreign investment and trade environment and optimize the domestic industry structure, and finally improve the quality of Chinese economy development and enhance the international competitiveness. Therefore, research on the global value chain dominated by Chinese enterprises under the "one belt one road” background has the important implication.

\section{THE OPPORTUNITY TO BUILD THE CHINA DOMINATING} VALUE CHAIN UNDER “ONE BELT ONE ROAD” BACKGROUND

On the world economic and political map, "one belt one road" is to the east of the Asia-Pacific economic circle and west of the European economic circle with an important position. It involves more than 60 countries and areas, covering around 4.4 billion population with the GDP of USD 23000 billion, accounting for $63 \%$ and $29 \%$ of the world respectively. At the adjusting stage after the international financial crises, various countries along the line are eager for 
development and expect to find new development pattern and regional cooperation. It has become the common view to strengthen the international cooperation and policy coordination, and meet the crises and challenges together. Since "one belt one road" proposal is put forward, over 100 countries and international organizations have taken part in. China has concluded the "one belt one road" cooperation agreement with over 30 countries along the line, and cooperated with over 20 countries in respect of the international production capacity. From nil to some and from point to surface, the global new opening pattern with the overall planning of "one belt one road", as well as the complement between east and west has gradually emerged. The speed and achievement is beyond expectation. Various countries along "one belt one road" have rich resources and labor as well as the broad market potential, Chinese enterprises may use their own advantage and grasp the opportunity to build the global value chain with themselves as the dominating party on basis of "one belt one road".

By participating in the international division of the product to integrate into the global value chain, improving the factor endowments during such course, and learning by doing, the developing countries may improve their position the value chain. However, participating in the international division of the product will not necessarily improve the position in the value chain and the division. It is also possible to be trapped into the "low end targeting". For example, many countries in southern Asia are still in the low end of the global value chain, due to their excessive dependence on the textiles export. The reason for such countries to be in the low end of the global value chain for a long time is related to the way they participate in the global value chain and the locking pressure of the high end, besides that they lack the core factor resources of the value chain. On one hand, such countries focus on the low cost production to attract investment while ignoring the cultivation of other factor resources. In the meantime, they are unable to improve the position in the value chain by participating in the international division, due to the technology barriers set up by the enterprises in the high end of the value chain. On the other hand, most developing countries entered the global value chain by way of original equipment manufacturer. However, the original equipment manufacturer might enter the capture value chain when facing the high technology study and independent innovation cost. Since putting forward the "one belt one road" concept, China has stick to the opening and cooperation, mutual benefiting and win-win to give consideration to the interests of various parties. Compared to most countries along "one belt one road", China is in a relatively high position in the global value chain. Cooperation with such countries is not to use their cheap labor and transfer the backward production capacity, but to reasonably allocate benefits, make full use of various parties' advantage and potential, and seek to co-build the value chain with the countries along the line, which could help them get rid of the low end in the value chain and break the monopoly of the developed countries to win more support for the global value chain dominated by China.

Since the break out of the global financial crises in 2008, EU has been slow in recovery. Insufficient investment is the main reason, which requires that EU should take action to create the stable economic, financial and rule environment to improve the attraction to foreign investment. Under such background, after Juncker assumed president of the EU committee, he put forward the investment plan up to 315 billion Euro Dollars in November 2014, say, "Juncker Plan". The purpose is to promote investment in the areas of infrastructure, new energy, information technology, etc. On 14 December 2015, the European Bank for Reconstruction and Development declared that they accepted China as the shareholder, and China formally became the member. The joining of China will connect the "one belt one road" proposal and the "Juncker Plan", which provides the broad space for the investment and cooperation between China and the Bank in middle and east Europe, eastern and southern Mediterranean Sea, middle Asia and etc. Both China and the Europe should take this opportunity to connect the "one belt one road" proposal and the "Juncker Plan", and achieve mutual benefiting and win-win. Besides the cooperation in the infrastructure, the European countries less exclude Chinese investors in the areas of the high new technology industry, high level manufacture, and etc. Chinese enterprises are less rejected in the mergers and acquisitions in Europe. One important reason for Chinese enterprises to invest in Europe is the "extended value chain". In the meantime, affected by the European debt crises, the price of many European good assets are in a historic low point, which is a good opportunity for Chinese enterprises to enter. For most of the developing countries along "one belt one road", their economic increase rate are higher than the world average level, and have great development potential and broad market space. However, because of the low economic development level, the market of many countries is not fully opened, and do not form the fixed pattern in the global value chain, which provides an opportunity for Chinese enterprises to enter.

In respect of different varieties of commodities, the importance of various factor resources in the value chain is different, while the exclusive occupier of the core factors is most likely to dominate the whole value chain. The labor intensive industries such as the clothing and toys belong to the value chain driven by the demand. The enterprises with brand and sales network are in the core position. The technology and capital intensive industries such as the computer, semiconductor, and high level equipment belong to the value chain driven by the producer. The multi-national corporations with core production technology dominate the global value chain. Taking clothing of the textiles industry for example, the clothing export of China previously depended on the low cost advantage and sold the products to foreign distributors, with no brand and marketing network abroad, and thus gained little profit in the whole clothing value chain. However, the clothing industry is highly competitive. No brand or distributor could occupy a large share in the market, which provides the opportunity for Chinese clothing enterprises to build their own brand and marketing network in foreign market. With rich design and production experience, Chinese clothing enterprises absolutely may occupy the high end of the value chain. The requirement of the technology and capital intensive products such as the machinery equipment for the technology and after-sales service is high. Recently, Chinese equipment 
manufacture industry has made great progress, although there is still distance from the developed countries in the area of technology and the research and development. However, generally, the economy of the countries and areas along "one belt one road" is less developed, and the demand for the sophisticated technology equipment is small, while the demand for Chinese equipment which is cheap but could satisfy the basic production need is high. If Chinese equipment enterprises could provide better after sales service and accelerate the technology upgrade, they are able to build the product value chain with the dominating position.

During the construction of "one belt one road", Chinese government sticks to the principle of joint negotiation, joint building, sharing, cooperation and win-win, and cooperate with the countries along the line in respect of the policy, infrastructure, trade, capital and civilian morale through the current bilateral and multi-lateral cooperation mechanism. The policy communication helps reducing the misunderstanding of foreign governments toward Chinese enterprises, and avoiding the unfair treatment on them when investing abroad. The infrastructure communication is to break the bottleneck of the regional transportation by improving the infrastructure construction, which helps countries along "one belt one road" participating more in the international division. Chinese enterprises may gain the first coming advantage in building the global value chain after the proceeding of the infrastructure construction. The smooth trade focuses on the convenience of the investment and trade, and removes the investment and trade barriers, which helps expanding the trade, optimizing the structure, enhancing the bilateral cooperation and optimizing the reasonable division of the domestic and abroad industry chain. The capital flow is the important support for the "one belt one road" construction. At this stage, although the capital provided by the government is mainly used in the infrastructure construction, it is expected that more financial support will be provided to overseas investment enterprises. The communication of the public mind is one of the five important links. It helps various parties in understanding each other, and also plays an irreplaceable role in helping Chinese enterprises knowing local market and the investment environment, improving the enterprise image, increasing the acceptance of foreign market, and thus helps Chinese enterprises integrating into local market. Up to 2016, the investment of China in the countries along "one belt one road" had been up to over USD 50 billion. Chinese enterprises have built 56 economy and trade cooperation zones in over 20 countries, and created nearly USD 1.1 billion tax and 180,000 employment posts. Such cooperation zones provide the effective platform for Chinese enterprises to understand the host countries, cooperation with the host countries' enterprises and gain more service and safeguard. With the promotion of various parties, "one belt one road" has made certain initial achievements: the construction of China-Russia Tongjiang railway-bridge has commenced; the renovation project stage II of China-Pakistan Karakoram Road and the Gwadar Port east bay express way are in smooth construction. The transportation, logistics, communication, international airlines and etc. have developed rapidly. Besides, the power station cooperation projects between China and some middle Asian countries, and the industrial park cooperation projects in Russia, India, Malaysia and Belarus are also in fast progress.

\section{The ChAllenges TO BUILD THE ChINA DOMinAting VALUE CHAIN}

Although "one belt one road" construction proposed by Chinese government and the current world economic environment provide the rare opportunity for Chinese enterprises to go out, there are still many challenges for them to build the global value chain dominated by them.

After the reform and the opening, the eastern area of China integrated the global value chain depending on the labor advantage and firstly achieved the economic increase. However, this did not lead the western area to develop correspondingly. Instead, the income gap between the east and the west is enlarged, and the industrial structure comes apart. Theoretically, when entering the global value chain, Chinese enterprises fully use the industry grade and domestic market formed by the east and the west by extending the global value chain to domestic market to build the national value chain, which not only helps the industry structure optimization and the regional coordination development, but also enable the pattern of China's participation in the value chain competition transfer from "link - chain" to "chain - chain", improve the position in upgrading domestic value chain, and finally building the self-dominating global value chain by extending the chain link. However, some research found that the domestic value chain was not successfully connected with the global value chain during the economic grow, and opening to abroad was separated from national opening. The separation between the domestic value chain and the global value chain leads to two dual national and international standards. It is difficult for the enterprises to use the advantage in the domestic value chain to build the international value chain, and thus is not helpful for coordinating the domestic industry structure upgrade and give play to the scale economy.

Chinese enterprises went out and tried to build selfdominating value chain only ten years ago, and many are still in the groping stage. At present, China has become the capital net exporting country, but a large amount of foreign investment has been in the developed countries and areas, such as the US. Although recently, the investment in the most developing countries along "one belt one road" has been increased rapidly, the involving areas remain the resource development, infrastructure and etc. The investment and experience in building its own industry chain and value chain are still relatively insufficient. In addition, with the improvement of Chinese enterprises' position in the division of the global value chain and the acceleration of overseas investment, some enterprises originally in the high end of the value chain set up barriers for the overseas plan of Chinese enterprises by the weapons such as the patent right. Because Chinese enterprises lack the accumulation of the strategic resources such as the technology, brand and etc. it is unavoidable that they meet the market barriers established by foreign transnational companies using patent right and brand, and thus causing trouble for Chinese enterprises to expand the value chain abroad. 


\section{RELEVANT ADVICE ON BUILDING THE CHINA} DOMINATING VALUE CHAIN

Although there are many challenges for Chinese enterprises in building the global value chain dominated by them, there are even more opportunities. Under the "one belt one road" background, the government should enhance the cooperation with the countries along the line on the principle of mutual benefiting and win-win, and remove the noneconomic barriers for the enterprises when they go out. In addition, Chinese enterprises should improve their ability and learn the global view, so as to have more bargain power in the global value chain competition.

First, the governments should enhance the coordination and negotiation to reduce the risk and drag force for the enterprise investment. Chinese enterprises have little experience in the "going out" strategy which is enforced for a short time. In those developed countries and areas where the market legal system is improved, the lawful rights of the enterprises may be respected and protected. However, in most of the countries along "one belt one road", the economy is undeveloped, and the market mechanism and legal environment is not complete. There are major risks for the enterprises to invest in local. Being different from Chinese policies to attract investment, many countries abroad wish to have foreign investment, but the government do not establish special agency to coordinate various issues of the foreign investment, resulting in that the enterprises investing locally could not be well serviced and protected. Therefore, it is necessary for the governments to coordinate and negotiate to make relevant laws and regulations to fully protect the lawful rights and interests of the enterprise investors. The government may also build the trade park by cooperation to provide local infrastructure, consulting and legal service for Chinese enterprises, and reduce the operation difficulties for the enterprise investment. Chinese government may also provide the official development assistance (ODA) to shape good image in the host countries and promote Chinese enterprises to set up the network for the investment and product sales in the host countries.

Second, Chinese enterprises should joint with the enterprises in the host countries to form interest community to achieve mutual benefiting and win-win. When investing abroad, many enterprises may enter other countries by establishing sole-investing enterprise in order to gain more profit and even occupy exclusively the market. Alternatively, they establish joint ventures with the enterprises in the host countries, but they are not willing to share the production technology and the marketing network. Generally speaking, the host government and the people will be on alert to foreign enterprises. If foreign investment is too strong, it will not be helpful for the investment plan; and there will even be difficulties in further operation. Joining with enterprises in the host countries into interest community helps breaking the restrictions to foreign enterprises; integrate into local culture in a faster way; and obtain irreplaceable advantage in marketing exploring and contact with the government. In addition, it will help the enterprises in the host countries improving the production and management level, and improve their position in the value chain. Comparing the low end locking of western transnational companies on the developing countries, the enterprises and government of the host countries more like the former. This will also add advantage to Chinese enterprises in the competition with the original high end enterprises in the value chain. Furthermore, Chinese enterprises should consider the interests of the people in the host countries in respect of the labor treatment, environment protection and etc. to gain the support of local people.

Last, China should pay attention to the harmonious development of the domestic and abroad value chain. The separate of the domestic value chain from the global value chain results in the dual industry structure domestically and abroad. Some export departments actively integrate into the global value chain. When satisfying the high quality requirement of the developed countries, they also obtain advantages in the technology and management compared to the departments and enterprises selling on domestic market. As reported by some media, Chinese citizen buy the "high end product" made in China in foreign countries, which indicates that the domestic industry chain is separate from the international one. The export enterprises with technology and management advantage fail to build the value chain in domestic market, and the domestic value chain is in low level resulting in the difficulties for the consumers to obtain high level products, which is neither helpful for shortening the gap of domestic regions and upgrading the industry structure; nor helpful for China to transfer to the economic grow pattern driving by domestic demand. Therefore, connecting the domestic value chain with the global value chain, and reasonably dividing different links of the value chain depending on the industry grads formed by the difference of domestic regions, will on one hand promote the backward enterprises to upgrade by integrating into the global value chain; and on the other hand may use the broad Chinese market to provide full market and capital safeguard for certain capable enterprises to go out to build the global value chain.

\section{CONCLUSION}

One side of "one belt one road" is the eastern Asia production network most active in economy with the countries that participate in the global value chain at a high degree. The other side is the European economic circle with the production network dominated by Germany and the middle and east Europe. The middle is the economy sunken area. Many countries are still at the initial industrialization stage. The infrastructure such as the railway, port, highway and etc. falls behind, which causes difficulty for such areas to share the achievement of the economic globalization. "One belt one road" is like a long and strong wing and holds the new pattern for the joint development of Asia and Europe. "One belt one road" is a large arena for various countries to achieve joint prosperity. It is not the one-man show of China. Its openness and inclusiveness brings infinite possibility for the world. The new node of joint building and sharing is coming for China and various countries along the line in the areas of transportation infrastructure, trade and investment, energy cooperation, financial cooperation, cultural communication and etc.. With the deepening of the reform and opening, Chinese enterprises will participate in the global value chain to 
a larger degree. By 2030, China will have become a large import country and built its own global value chain network. China will connect the industry transfer abroad and the "one belt one road" construction. By increasing foreign investment, China will gradually establish the regional and global production network and the global value chain system dominated by China.

\section{ACKNOWLEDGMENT}

Hu Feng is the corresponding author of this thesis.His deepest gratitude goes foremost to Academician Zhu Zunquan and Prof. Tang Haiyan. Without their consistent and illuminating instructions, this thesis could not have reached its present form.

\section{REFERENCES}

[1] Kull T J, Ellis S C, "Narasimhan R. Reducing behavioral constraints to supplier integration: A socio - technical systems perspective",Journal of Supply Chain Management, 2013, 49(1),pp64-86.

[2] Kuroiwa I, Kuwamori H.,"Impact of the US economic crisis on East Asian economies: production networks and triangular trade through Chinese mainland",China \& World Economy, 2011,19(6),pp1-18.

[3] Shih W C.,"What it takes to reshore manufacturing successfully",MIT sloan management review, 2014, 56(1),pp55-62.

[4] Wang Ting, "Study on the Scientific Research Group Management of Chinese High Technology Enterprises from the Perspective of Knowledge Transfer", IJEME, vol.2, no.3,2012, pp.57-63.

[5] Zhou Haiyan,"Study on the Transform and Upgrade Strategy of Chinese Textile Processing Enterprises", IJEME, vol.2, no.3,2012, pp.32-38. 